\title{
O DESENVOLVIMENTO NORMATIVO DO DIREITO ELEITORAL NO PERÍODO IMPERIAL BRASILEIRO
}

\section{THE NORMATIVE DEVELOPMENT OF THE ELECTORAL LAW IN THE BRAZILIAN IMPERIAL PERIOD}

\author{
${ }^{1}$ Wagner Silveira Feloniuk
}

\section{RESUMO}

Análise normativa do sistema eleitoral brasileiro durante o Período Imperial. O Direito Eleitoral é estudado com enfoque em fontes primárias para descrever o sistema eleitoral e as principais inovações e leis do período. A Constituição de 1824, a alteração das eleições municipais, a Lei dos Círculos, a Lei do Terço e a Lei Saraiva formam os principais sistemas que marcaram a tentativa não exitosa de estabelecimento de um regime menos conflituoso e propenso a falhas. Também é dada atenção à atuação dos magistrados, que continuam sendo protagonistas importantes e que, com a evolução normativa, cada vez mais recebem atribuições que mais tarde justificariam a criação da Justiça Eleitoral em 1932.

Palavras-chave: Direito eleitoral, Período imperial, Lei saraiva, Lei dos círculos, Lei do terço

\begin{abstract}
Normative analysis of the Brazilian electoral system during the Imperial Period. The Electoral Law is studied to describe the electoral system with a focus on primary sources and the main innovations and laws of the period. The Constitution of 1824, the alterations of municipal elections, a Lei dos Círculos, a Lei do Terço e a Lei Saraiva created the main systems that marked the unsuccessful establishment of a less confrontational and prone to failure regime. Attention is also given to the role of judges, which remain important protagonists, and with the normative evolution, increasingly receive assignments that later will justify the creation of the Electoral Justice in 1932.
\end{abstract}

Keywords: Electoral law, Imperial period, Lei saraiva, Lei dos círculos, Lei do terço

\footnotetext{
${ }^{1}$ Doutor em Direito pela Universidade Federal do Rio Grande do Sul - UFRGS, Porto Alegre - RS (Brasil). Professor da Universidade Federal do Rio Grande do Sul - UFRGS, Porto Alegre - RS (Brasil).

E-mail: wagner.feloniuk@gmail.com
} 


\section{INTRODUÇÃO}

O trabalho apresenta uma análise normativa do Direito Eleitoral durante o período imperial brasileiro. O principal objetivo é apresentar as normas que mais influíram no desenvolvimento eleitoral e apresentar o crescente papel dos magistrados. A análise das normas serve para demonstrar como o império foi marcado pela instabilidade e as dificuldades de se criar um sistema em que o sufrágio tivesse uma ligação forte com a ideia liberal de poder emanado pelo povo. Por outro lado, o papel dos magistrados, que já era muito relevante durante o período colonial, foi expandido ao longo da sucessão de leis e terminou o período imperial com todas as características que necessitaria para que, poucas décadas depois, fosse criada a Justiça Eleitoral.

A pesquisa utiliza análise doutrinária, mas há maior enfoque reconstrução do sistema eleitoral com o uso de fonte primária normativa - as próprias normas desse período. A divisão introduz o sistema anterior, colonial e, então, estuda cada lei de maior relevância separadamente, inserindo nessas seções as normas menores que orbitaram as alterações de maior impacto.

\section{ORIGENS COLONIAIS}

O Direito Eleitoral brasileiro é de origem portuguesa e foi implantado muito precocemente. A primeira eleição, realizada por Martim Afonso de Souza, foi em 22 de agosto de 1532, e nenhuma anterior é datada na América. Foram, muito provavelmente ${ }^{1}$, utilizadas as Ordenações Manuelinas, que logo seriam sucedidas pelas Filipinas e estas vigorariam nas eleições municipais brasileiras até 1828. Poucas diferenças haviam entre as duas normas. As eleições municipais brasileiras mantiveram alguma semelhança por mais de três séculos, a começar da primeira, no século XVI, até o momento em que o Brasil tinha um imperador, no século XIX.

\footnotetext{
${ }^{1}$ Não foram encontrados dados confiáveis sobre o acontecimento.
} 
Esse foi um momento em que floresceu a influência municipal. Apesar da centralização dos capitães, governadores-gerais e, posteriormente, vice-reis, as dificuldades de comunicação e a cultura de sufrágio fez com que as câmaras municipais tivessem grande influxo e poder. No período, anterior à divisão dos poderes, muitas das funções estatais acabavam sendo cumpridas por membros das câmaras - entre os membros havia um juiz, além de ao menos dois vereadores e um procurador.

Nesse período inicial, as Ordenações Filipinas, no Livro I, Título LXVII, traziam detalhadamente os procedimentos eleitorais (PORTUGAL, 1870, p. 156). Era um sistema de dois graus, em que "os homens bons" reunidos votavam cada um em seis pessoas. Mais tarde, um magistrado iria formar pares de acordo com critérios estabelecidos em leis, e esses três pares seriam responsáveis por apontar todos detentores de cargos eletivos. $\mathrm{O}$ mandato era de um ano, mas como três listas eram formadas pelos pares, cada eleição apontaria os representantes para os próximos três anos - ao final de cada um, um menino faria a escolha da próxima lista. $\mathrm{O}$ sistema não era desprovido de conflitos, tendo sido publicadas diversas normas tentando aprimorar e pacificar o sistema, como o Alvará de 1611. Apesar dos problemas políticos sérios, houve estabilidade normativa no período e poucas alterações no cerne do sistema (FERREIRA, 2001, p. 55).

O sistema narrado acima era utilizado nos municípios brasileiros. Enquanto houve um rei que governava sob as normas do antigo regime, não houvera necessidade de eleições gerais. Isso vai ser modificado a partir de 1797 e do início da campanha militar de Napoleão Bonaparte. As vitórias em terra permitiram ao imperador conquistar grande parte do território europeu. No mar, no entanto, a potência da Inglaterra prevaleceu e isso ficou definitivamente selado com a histórica batalha de Trafalgar, de 1805, quando Espanha e França foram derrotadas no mar (JUL, 2004, p. 47).

Procurando sufocar a Inglaterra, Napoleão impõe um embargo. $\mathrm{O}$ pequeno reino de Portugal, sem nenhuma opção segura, continuou defendendo a Inglaterra, aliada histórica. Por essa posição, os portugueses foram invadidos pela França e a família real veio para o Brasil em 1807. A partir daquele momento, a Inglaterra teria livre comércio com o Brasil ${ }^{2}$, estabelecendo uma quase hegemonia comercial (FAORO, 2001, p. 295-297) e reformas realizadas

\footnotetext{
2 O comércio era livre no sentido de estar, pela primeira vez, aberto às nações amigas de Portugal sem o intermédio dos portos portugueses. Havia, ainda, o pagamento de $15 \%$ sobre os produtos ingleses. Essa alíquota é inferior aos

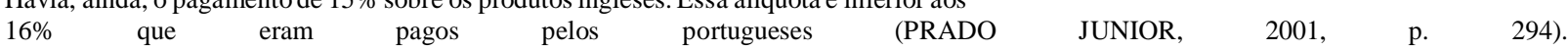


pelo monarca geraram um grande desenvolvimento para as instituições brasileiras (PRADO JÚNIOR, 2010, p. 47). Portugal, por outro lado, perdera a família real, a maior parte de sua burocracia, metade do dinheiro circulante e o domínio sobre o comércio com a colônia que mantinha sua economia funcional. Não menos de um sexto da população do país, cerca de quinhentas mil pessoas, morreriam de fome ou em batalhas nos anos que seguirem a vinda de Dom João VI (GOMES, 2011, p. 64-74).

Essa série de fatores haviam se tornado motivo de insatisfação para os portugueses, invadidos pelo inimigo e enfrentando dificuldades econômicas e sociais tão profundas (CAIRU, 1827, p. 12). Simbolicamente, a metrópole virara colônia, era governada pela única dinastia real europeia na América, subordinada a uma terra distante que fora fonte de recursos por três séculos (MAIA, 2002, p. 248-249). Com a queda de Napoleão em 1815, os motivos para a permanência da família real no Brasil deixaram de existir e a insatisfação existente passou a ser maior (BERBEL, 2006, p. 184), desejavam o rei e as antigas vantagens comerciais (BERBEL, 2006, 228).

Exigia-se a volta do rei, mas o espaço político aberto em Portugal com o afastamento fez com que teses liberais de limitação do poder real fossem também defendidas (BONAVIDES, 2012, p. 2012). Os nobres e comerciantes visavam fazer com a volta fosse concomitante com a criação de uma Constituição de natureza liberal, como fizeram a França, os Estados Unidos e a Espanha no período, limitando o poder do monarca e separando os poderes. Como o exemplo francês viera marcado por uma revolução longa e violenta, a Espanha e sua história de luta contra o invasor Francês seriam a maior inspiração.

Em 24 de agosto de 1820, iniciou a revolução no Porto que logo seria recepcionada em Lisboa e daria origem aos acontecimentos que determinaram a volta de Dom João VI à Portugal. Após alguns conflitos sobre a escolha do sistema eleitoral que elegeria os representantes responsáveis por elaborar a nova Constituição de Portugal, foi decidido utilizar o sistema de eleições em quatro graus previsto na Constituição Política da Monarquia Espanhola, a Constituição de Cádiz (PORTO, 2002, p. 22-24). Essa revolução se solidificaria em Portugal e viria até a ter adesões no Brasil, como ocorreu com Grão-Pará (CAIRU, 2011, p. 38).

Afinal, Dom João VI publicou um manifesto em 21 de fevereiro de 1821 aderindo ao movimento (ARMITAGE, 1937, p. 17) e, após mais pressões, aceitou voltar pessoalmente à Portugal, conforme exigiram os portugueses. No mês seguinte, em 7 de março, o monarca publicou um decreto que estabeleceu a regência do príncipe herdeiro, Dom Pedro, a volta do 
rei e o uso da Constituição de Cádiz como lei eleitoral para as primeiras eleições gerais do Brasil (BONAVIDES; AMARAL, 2012, p. 491-492).

Foi realizada a eleição para a escolha dos representantes brasileiros que iriam a Lisboa auxiliar na elaboração da Constituição. O início das eleições gerais no Brasil se deu com as normas da Constituição espanhola ${ }^{3}$, conforme apontam o Diário das Cortes Gerais de Portugal (PORTUGAL, 1821) ${ }^{4}$. Nesse processo é que a Constituição de Cádiz seria outorgada por um dia no Brasil, em 21 de abril de 1821.

Apesar das tentativas, não haveria sucesso no objetivo de manter os reinos unidos. A independência foi proclamara em 7 de setembro por Dom Pedro e a assembleia luso-brasileira, convocada antes da independência (BONAVIDES; ANDRADE, 1989, p. 34-35), em 3 de junho de 1822, passaria a atuar como assembleia constituinte - até sua dissolução em 11 de novembro do mesmo ano. Depois desse momento se caracteriza o Direito Eleitoral da fase imperial, ainda antes da Constituição de 1824, mas após a substituição do sistema espanhol (FRANCO, 1957, p. 232). Começaria agora a evolução de um sistema brasileiro que manteria características semelhantes por quase um século, mantendo a força do magistrado na maior parte das oportunidades, mas tentando vencer importantes dificuldades para a sua aplicação com menos conflitos e interferências de políticos locais.

\subsection{Instruções de 19 de junho 1822}

A partir do término do período de trezentos anos de sistema eleitoral do Brasil colonial, uma sucessão rápida de normas se instala (JORGE, 2004, p. 37). A apresentação profunda de todas as leis promulgadas exigiria um esforço de dimensões maiores e muitas trouxeram alterações pontuais. Assim, serão analisadas apenas as principais do período. Das leis de menor relevância, apenas haverá a referência aos seus pontos mais fundamentais ou sua existência

A primeira lei eleitoral brasileira, no entanto, não participa do grupo de leis de menor importância. Ela inaugura o novo momento, já mais semelhante com a realidade liberal do império - e começa a desenhar o que seria a limitação do voto pela renda.

\footnotetext{
3 É neste período, em 21 de abril de 1821 que a Constituição de Cádiz é outorgada no Brasil após uma revolta da população na Praça do Comércio, no Rio de Janeiro, que exigia sua vigência enquanto era elaborada a nova constituição. A vigência duraria apenas um dia, sendo revogada após uma violenta repressão contra os revoltosos (MELLO MORAES, 1871, p. 45).

4 Ata de 18 de fevereiro de 1821.
} 
Dom Pedro I criou uma Assembleia Nacional Constituinte para entregar ao Brasil independente a sua primeira Constituição, em 3 de junho de 1822 (FRANCO, 1994, p. 23-26) e, para a escolha dos membros, convocou eleições. Em função de sérios embates políticos e da vontade de centralizar o poder por parte do monarca, a assembleia seria dissolvida pouco tempo depois. Apesar da derrocada do colegiado, a primeira norma eleitoral de escolha vigeu a partir de 19 de junho de 1822.

Seria uma assembleia de cem deputados, formada de acordo com a composição das províncias. Para votar, o eleitor deveria ter vinte anos ou ser casado, não ser filho-família, e ter um ano de residência na freguesia onde exerceriam o voto. Continuando a tradição liberal, estavam excluídos da votação todos os que recebem salário ou soldos exceto os guarda-livros, os primeiros-caixeiros das casas comerciais, administradores de fazenda e fábrica e alguns criados da casa real. Também estavam excluídos os religiosos regulares, os estrangeiros não naturalizados e os condenados por crimes. Essas eram as disposições dos artigos $8^{\circ}$ e $9^{\circ}$.

Surgia o desenvolvimento que culminaria no voto censitário. Nesse momento, no entanto, ainda não se exigia a comprovação de rendas e altos empregados poderiam votar. A instituição, conhecida desde o Direito Romano, no século II a. C. (MICHELS, 2002, p. 23), só seria aplicada a partir da Constituição de 1824.

O sistema eleitoral era composto de dois graus - em um procedimento indireto. O povo escolhia eleitores e esses elegeriam os deputados. Ainda não havia qualificação ou registro, nenhum requisito prévio para habilitar à eleição. Cabia aos párocos organizar as eleições, fixando editais nas paredes exteriores das igrejas. Nos editais deveria conter o número de "fogos" da localidade (moradias - e havendo mais de uma família nelas, considerava-se haver outro fogo) (FERREIRA, 2001, p. 122).

A cada cem fogos, haveria um eleitor. Havia regras de adaptação: se houvessem cento e cinquenta, seria o bastante para ter o segundo eleitor e assim por diante. No dia determinado, o povo se reuniria para votar nesses eleitores. Cada votante deveria escolher tantos nomes quanto seriam os eleitores. Se não soubessem ler, diriam ao secretário os nomes dos escolhidos e os votantes assinariam com uma cruz. Estavam eleitos aqueles que alcançassem a maior quantidade de votos (FERREIRA, 2001, p. 123-124).

Os eleitores de paróquia deveriam se reunir em data marcada - quinze dias após a sua eleição - nas cabeças de distrito de suas freguesias, cidades maiores estabelecidas em lei, e ali elegeriam os deputados. Por exemplo, Minas Gerais teria 20 representantes, São Paulo teria 9, o critério era populacional. A votação dos eleitores de paróquia era semelhante à do primeiro 
grau: cédulas individuais, assinadas, com o número de nomes correspondente ao de deputados a serem eleitos (FERRIRA, 2001, p. 123-125).

Efetivada a dissolução, uma comissão rapidamente elaborou a Constituição Política do Império do Brasil, de 1824, que seria outorgada pelo imperador em 25 de março daquele ano.

\section{CONSTITUIÇÃO DE 1824 E A NOVA LEI ELEITORAL DE 1822}

As eleições ocorreram, a assembleia, contudo, não chegaria a elaborar a nova Constituição. Antes de completar sua missão, ela foi dissolvida (BONAVIDES, 1989, p. 43 71). Dom Pedro I rapidamente faz elaborar a nova Constituição, fortemente baseada no projeto da anterior (HOMEM DE MELLO, 1863, p. 25) e em outras constituições liberais. A alteração mais profunda trazida por Dom Pedro I foi a introdução de uma novidade institucional, o Poder Moderador, uma adaptação da doutrina do francês Benjamin Constant. A ideia de um Poder Moderador $^{5}$ fora prevista em teoria menos de dez anos antes da carta, e nunca aplicada antes. Além disso, ele alterou aspectos do antigo projeto em normas que diminuiriam o seu poder além do que o monarca desejava.

Afirmava o monarca que seu trabalho renderia um texto duplamente mais liberal que a da assembleia dissolvida (BONAVIDES, 1989, p. 75-76). Não foi esse o resultado: a proposta da assembleia era de limitar bastante o seu poder, a nova carta dava poderes mais extensos ao imperador.

Sobretudo, cabe trazer que o sistema previsto nas Instruções de 1822 não foi modificado de maneira substancial na nova carta constitucional. Os Deputados, Senadores e membros dos Conselhos Gerais das Províncias seriam eleitos através de um sistema indireto de dois graus cidadãos escolhem eleitores de paróquia; esses, os representantes.

\footnotetext{
5 Benjamin Constant não utilizava a expressão Poder Moderador. A expressão mais utilizada na sua obra "Princípios de Política, Aplicáveis à todos os Governos Representativos e Particularmente à Constituição Atual da França" era Poder Real, a ser exercido por um monarca sem os poderes típicos de um Chefe de Governo, cabendo a ele apenas harmonizar as relações entre os outros poderes quando fosse necessário. Era irresponsável exatamente por não ter nenhuma atribuição que o pudesse tornar perigoso (CONSTANT, 1815, p. 34-44). O doutrinador prevê a possibilidade de o Poder Real ser utilizado concomitantemente ao Poder Executivo com a seguinte passagem, condenando a ideia: "o rei cessa de ser neutro, ele seria um ministro mais do que terrível, porque associa à inviolabilidade que possui as atribuições que não deveria jamais possuir. Então essas atribuições destroem toda a possibilidade de repouso, toda a esperança de liberdade" (CONSTANT, $1815, \quad$ p. $\quad 159), \quad$ livre.
} 
Art. 90. As nomeações dos Deputados, e Senadores para a Assembléa Geral, e dos Membros dos Conselhos Geraes das Provincias, serão feitas por Eleições indirectas, elegendo a massa dos Cidadãos activos em Assembléas Parochiaes os Eleitores de Provincia, e estes os Representantes da Nação, e Provincia. (BRASIL, 1824).

Dessa votação poderiam participar todos os que preenchessem os requisitos dos artigos 92 e 94 - e esses também eram os passíveis de serem eleitos, respeitada a necessidade crescente de renda para ocupar cargos de maior representatividade.

Art. 92. São excluidos de votar nas Assembléas Parochiaes.

I. Os menores de vinte e cinco annos, nos quaes se não comprehendem os casados, e Officiaes Militares, que forem maiores de vinte e um annos, os Bachares Formados, e Clerigos de Ordens Sacras.

II. Os filhos familias, que estiverem na companhia de seus pais, salvo se servirem Officios publicos.

III. Os criados de servir, em cuja classe não entram os Guardalivros, e primeiros caixeiros das casas de commercio, os Criados da Casa Imperial, que não forem de galão branco, e os administradores das fazendas ruraes, e fabricas.

IV. Os Religiosos, e quaesquer, que vivam em Communidade claustral.

$\mathrm{V}$. Os que não tiverem de renda liquida annual cem mil réis por bens de raiz, industria, commercio, ou Empregos

\section{$[\ldots]$}

Art. 94. Podem ser Eleitores, e votar na eleição dos Deputados, Senadores, e Membros dos Conselhos de Provincia todos, os que podem votar na Assembléa Parochial. Exceptuam-se

I. Os que não tiverem de renda liquida annual duzentos mil réis por bens de raiz, industria, commercio, ou emprego.

II. Os Libertos.

III. Os criminosos pronunciados em queréla, ou devassa (BRASIL, 1824).

Ampliavam-se, no entanto, as restrições relacionadas ao patrimônio, pois foi implantado o voto censitário: para poder votar, era necessário provar renda anual de cem mil reis por bens imóveis, indústria, comércio ou emprego. Os empregados também estavam impedidos, excetuados os mesmos das instruções - votavam apenas os guarda-livros, primeiros caixeiros das casas de comércio, os criados da casa imperial que não fossem de galão branco, e os administradores de fazendas e fábricas. Outras restrições existiam, mas essas desligadas da renda: idade mínima de 25 anos, salvo casamento ou graduação; filhos-família; religiosos; libertos; criminosos pronunciados. Para ser eleito, além desses requisitos, novos foram impostos. Para se eleger deputado, era necessária renda de quatrocentos mil réis, conforme o art. 95, I. Para o cargo de senador, era necessária de oitocentos mil réis, além de ter quarenta anos - art. 45, IV. 
Em todas as vilas e cidades se criariam câmaras municipais, e nelas haveria eleições para o número de vereadores que a lei determinasse - arts. 167 e 168 . Nesse momento, a organização política já permitia ver na câmara funções mais semelhantes às atuais prefeituras - sem juízes participando de sua composição.

A carta constitucional foi outorgada em 25 de março de 1824. No dia seguinte, foram criadas novas instruções para a realização das eleições (FERREIRA, 2001, p. 143). Os dados realmente importantes do sistema eleitoral vigente eram, no entanto, os da Constituição - acima apresentados. As normas das Instruções de 1822 continuaram quase inalteradas.

As eleições seriam realizadas dentro de uma igreja. Não havia nenhuma norma tratando dos eleitores que não soubessem escrever - não estava impedida sua votação, mas não se explicava como eles assinariam suas cédulas. $\mathrm{O}$ voto por procuração também foi permitido nessas leis (FERREIRA, 2001, p. 143-148).

Nesse momento é verificada uma constante do período imperial, de leis de pequena importância com alterações pontuais. Em 26 de março de 1824, se unificou o dia das eleições no Brasil e se apelou à consciência dos que votavam para que se elegessem homens probos; em 29 de julho de 1828, se estabeleceu multas para os que faltassem às eleições; o Decreto 6, de novembro de 1828, melhorava a organização dos colégios eleitorais (FERREIRA, 2001, p. 151152).

A Lei de 12, de outubro de 1832, foi a mais relevante nesse momento imediatamente posterior à vigência da nova carta. Ela permitiu aos deputados eleitos o direito de modificar a Constituição. Em função dela foi possível criar o Ato Adicional de n. 16, de 12 de agosto de 1834. Ela modificou as regras para a eleição dos regentes durante a menoridade do monarca. Se estabelecia que não seriam mais os representantes eleitos que escolheriam os regentes - os eleitores de paróquia, aqueles escolhidos pelos cidadãos, seriam os responsáveis pela escolha (FERREIRA, 2001, p. 152-154).

\subsection{Alteração das eleições municipais}

As Ordenações Manuelinas (cuja elaboração terminou em 1495) vigeu até 1828 e a eleição dos municípios no Brasil se manteve basicamente inalterada. O sistema eleitoral brasileiro começou a evoluir rapidamente a partir de 1821, mas não envolveu os governos locais durante os primeiros anos. Apenas em $1^{\circ}$ de outubro de 1828 , se alterou a forma de eleição dos representantes municipais (FERREIRA, 2001, p. 159). 
O novo sistema municipal se adequava e copiava as normas da Constituição de 1824 . Poderiam votar e serem eleitos aos cargos municipais, de acordo com o artigo $3^{\circ}$, todos os que cumprissem os requisitos descritos na Constituição - a renda para esses cargos, portanto, era de cem mil réis (BRASIL, 1828).

As câmaras eram compostas de nove membros nas cidades e sete nas vilas, além de um secretário (art. $1^{\circ}$ ). As eleições eram feitas no dia 7 de setembro em todas as cidades, vilas ou lugares nos quais houvesse câmaras. Os mandatos teriam duração de quatro anos. Para ser eleito, era necessário estar morando há dois anos no local.

O sistema eleitoral municipal, portanto, era direto, a continuidade da tradição. Uma relevante novidade da lei era que os eleitores com o direito de votar pela primeira vez seriam listados antes das eleições e fixados nas portas da igreja matriz da cidade conforme o artigo $5^{\circ}$ (BRASIL, 1828).

A alteração das leis municipais se deu, portanto, em adaptação à Constituição. Como consequência, foi estabelecido o voto censitário. Foi uma sensível diminuição do conteúdo democrático das eleições.

\subsection{Papel dos magistrados na Constituição de 1824}

A Constituição de 1824 não chega a cuidar de detalhamentos do papel dos magistrados nas eleições. O capítulo VI, das eleições, tem apenas oito artigos bastante sintéticos.

As Instruções de 26 de março de 1824, que regraram as eleições, retomam a tradição brevemente interrompida em 1822 de dar importante papel ao magistrado. O presidente da comissão eleitoral é o juiz ordinário ou juiz de fora da localidade. Ao seu lado estaria o pároco, dois cidadãos para serem secretários e dois escrutinadores - escolhidos por aclamação.

Assim, o papel do juiz nas eleições brasileiras retoma sua jornada. O juiz é, novamente, um administrador principal das eleições, responsável por sua organização. Além disso, ele também era o responsável pela aplicação de multas e outras penalidades - um aspecto misto entre a jurisdição e a Administração.

$\mathrm{Na}$ lei de 1828, relacionada às eleições municipais, se reafirmava o papel de administrador e organizador do juiz. Eles eram os responsáveis por fazer as listas gerais de eleitores e publicar elas nas postas das igrejas - conforme diz o artigo $5^{\circ}$. Era também ele o responsável pela contagem dos votos dos cidadãos. 
O papel jurisdicional do magistrado durante as eleições está mais claro agora que há previsão de um judiciário separado do executivo - algo que as ordenações não faziam. $\mathrm{O}$ artigo 88 da lei de 1828 cria a possibilidade de se aplicar multas, cabendo apelação. Os casos a serem resolvidos poderiam ser menores, mas sem dúvida ao lado do papel administrativo, o juiz também era o agente estatal imbuído do poder de resolver as controvérsias - um dos aspectos da jurisdição (CINTRA; PELLEGRINI; GRINOVER; DINAMARCO, 2007, p. 145).

\section{LEIS ELEITORAIS DO PERÍODO IMPERIAL}

\subsection{Desenvolvimento político após primeiras eleições gerais}

A história de instabilidade política - e desvio do sistema eleitoral de sua finalidade começa a ter mais repercussão com a instalação do império. As eleições para as Cortes de Lisboa e da Assembleia Constituinte não registraram nenhum incidente grave nesse sentido em 1821 e 1822. As dificuldades existentes tomaram novas proporções.

Nas eleições de 1830, os membros dos partidos políticos do império já estavam atuando, ainda que os partidos fossem ser estabelecidos oficialmente apenas no ano seguinte. A partir do surgimento do Partido Restaurador, do Republicano e do Liberal, que surgem em 1831, a instabilidade relacionada ao Direito Eleitoral foi, em um quadro amplo, crescente até a república. Em 1837, exemplificando o novo cenário, houve tantas fraudes nos colégios de Lagarto, em Sergipe, que o governo decidiu anular o pleito completamente - essa não foi uma situação particular, a existência de violações à lei era sistemática (FERREIRA, 2001, p. 167168).

Os relatos são até mesmo de violência física: a pancadaria eventualmente decidia o partido que organizaria a mesa, e só depois disso, as eleições ocorriam. No segundo grau a situação não era melhor, e fraudes ocorriam em ampla escala (FERREIRA, 2001, p. 168-169).

O resultado dessa instabilidade política foi o surgimento de uma vasta legislação, tentando aprimorar o sistema, diminuir as instabilidades sociais e os conflitos decorrentes dos pleitos (FAORO, 2001, p. 432-433). Muitos são os diplomas eleitorais editados nesse período. É uma constante tentativa de estabelecer um ambiente institucional funcional para a realização das eleições 6 .

\footnotetext{
6 Uma lista com a caracterização sucinta das principais leis do período foi elaborada por Joel Candido (CANDIDO, 2010, p. 29-30).
} 
Nas palavras de Faoro, a sucessão de leis era um sinal das características do sistema que se instalara em 1837 e continuaria vigendo até 1889: "o sistema representativo será a imensa cadeira do 'cabresto' e do comando da vontade do eleitor" (2001, p. 430).

O Decreto n. 157, de 4 de maio de 1842, foi um dos exemplos mais claros das dificuldades geradas pelas eleições e das tentativas de aprimorar o sistema. Sua finalidade era tornar mais claro e legítimo o processo eleitoral, mas isso foi feito por meio de requisitos que sugeriam problemas profundos. A norma determinava a criação de duas listas eleitorais. Em uma ficaria a lista de todos os "fogos" da cidade; na outra, a lista de todos os cidadãos ativos. As listas deveriam ser formadas de acordo com os quarteirões da cidade e estar em ordem alfabética. Também essa legislação excluiu a possibilidade de voto por procuração. A presidência da organização continuava com o juiz, auxiliado pelo pároco e outros cidadãos (CANDIDO, 2010, p. 30).

Apenas dois anos depois, veio a lei de 19 de agosto de 1846. Foi a primeira lei criada a partir de um processo legislativo - feita pelo Congresso. Ela foi uma das leis mais discutidas, ponderadas e desenvolvidas de toda essa época. É um marco de sensível relevância no direito eleitoral brasileiro. As listas de eleitores passaram agora a ser feitas periodicamente e um censo do império foi previsto a cada oito anos (FERREIRA, 2001, p. 182-187). Essa lei continuaria vigendo durante longo período, inclusive depois da lei dos círculos no que tange à qualificação dos eleitores, restrições do voto, exigências para a candidatura e outros.

\subsection{Lei dos Círculos}

Em 19 de setembro de 1855 foi promulgada a Lei dos Círculos - o Decreto n. 842. Foi uma alteração importante e mais uma tentativa de melhorar o sistema eleitoral do período.

Com a Lei dos Círculos todas as províncias do império foram divididas em distritos e mantida a eleição indireta em dois graus. Haveria tantos distritos quanto deputados a serem eleitos pela província. Os eleitos agora deveriam obter maioria absoluta dos votos em escrutínio secreto, podendo haver uma segunda eleição com os quatro mais votados se isso não fosse alcançado na primeira apuração (art. $1^{\circ}, \S 6$ ). O número de deputados em cada província fora determinado na própria lei ${ }^{7}$.

\footnotetext{
7 Decreto n. 842, artigo $1^{\circ}$, $\$ 16$ : “A Assembléa Provincial da Bahia terá 42 membros, a tres por Districto; a de Minas Geraes 40 , a dous por Distrito; a de Pernambuco 39, a tres por Districto; a de S. Paulo 36, a quatro por Districto; a do Rio de Janeiro, tantos quantos derem os seus Districtos á razão de 5, exceptuados o Districto ou Districtos da Côrte, e seu Municipio; a do Ceará 32, a quatro por Districto; as de S. Pedro e Maranhão 30, a cinco por Districto; a do Pará 30, a dez por Districto; as das Alagoas e Parahíba 30, a seis por Districto; a de Sergipe 24, a seis por Ditricto; a de Piauhy 24, a oito por Districto; as de Goyaz, Rio Grande do Norte e Matto Grosso 22, a onze por Districto; as de Santa Catharina, Espirito Santo, Amazonas e Paraná 20"
} 
Assim, havia agora círculos eleitorais em todas as províncias. Era a instauração do sistema de votos hoje conhecido como distrital. Foi a aproximação brasileira ao instituto existente nos Estados Unidos, Inglaterra e França - a inspiração direta foi na lei eleitoral francesa de 22 de dezembro de 1789 (FERREIRA, 2001, p. 195-198). Aprimorando e dirimindo controvérsias da Lei dos Círculos, outras legislações surgiriam - de 23 de agosto de 1856, de 27 de setembro de 1856 e o Decreto de 18 de agosto de 1860. O mais relevante foi esse último, que diminuiu em um terço o número de distritos, estabelecendo que três deputados seriam eleitos em cada um deles.

As medidas não tiveram o condão de modificar os problemas enfrentados pelo Brasil nas suas eleições. As dificuldades do império para lidar com seus pleitos continuavam. A decorrência da instabilidade política foi a abundância legislativa: continuaram sendo editadas leis tentando aprimorar o sistema. Agora também estava em pauta a pressão do partido liberal pelo sistema direto de eleição.

Nesse período, especialmente após 1870, o sistema eleitoral brasileiro passou a ser um dos temas mais discutidos. Ferreira escreve que as lutas políticas do Império eram travadas em volta do sistema eleitoral, no qual os problemas de fraude e corrupção imperavam (2001, p. 225).

\subsection{Lei do Terço e a ampliação do papel do magistrado}

Em 1875, ainda na busca por eleições mais desenvolvidas, surgiu o decreto de 20 de outubro - complementado e regulado pelo Decreto n. 6.097 de 12 de janeiro. O seu nome popular foi Lei do Terço, já que para dar mais espaço às minorias políticas, a cada eleitor de segundo grau teria um número de votos de apenas dois terços do número de deputados a serem eleitos.

Os eleitores de segundo grau normalmente elegiam representantes de seus partidos. Se São Paulo fosse eleger nove deputados, cada eleitor poderia votar em até nove nomes e, quase invariavelmente, o partido que tivesse mais eleitores escolheria a totalidade dos deputados, pois seus eleitores votariam todos nos mesmos nomes. A inovação da Lei do Terço foi determinar que apenas dois terços dos cargos pudessem ser ocupados pelos partidos que tivessem a maioria no segundo grau, o restante ficaria com os partidos com menos eleitores. 
Os problemas nem sempre estavam resolvidos, a existência de coligações entre partidos geravam dúvidas sobre como preencher o terço da minoria. Foi mais uma tentativa de sucesso apenas relativo no nosso desenvolvimento eleitoral (FERREIRA, 2001, p. 248).

O juiz de paz mais votado seria o responsável por organizar as eleições. Ele seria o responsável por organizar listas eleitorais que deveriam conter uma qualificação detalhada: nome, idade, estado, profissão, declaração de alfabetização, filiação, domicílio e renda reconhecida. Várias disposições a respeito de cada um desses dados foram feitas especialmente sobre a comprovação da renda. Foi a norma mais detalhada nesse quesito até aquele momento.

No artigo $1^{\circ}, \S 19$ surge uma inovação: o título eleitoral - chamado ali de título de qualificação. Era o início de uma tradição que iria se perpetuar pela história eleitoral brasileira. A previsão era simplória naquele momento, dizia que seria extraído um título a todos os eleitores que cumprissem os requisitos de qualificação impostos pela lei.

Art. $1^{\circ}, \S 19$. Satisfeitas todas as formalidades prescriptas nos paragraphos antecedentes e lançadas pelas Juntas municipaes as listas geraes em livro especial, que ficará no archivo da Camara do municipio, está ultimada e encerrada a qualificação; e a todos os cidadãos irrevogavelmente inscriptos na lista se passarão titulos de qualificação, que deverão ser impressos e extrahidos de livros de talão (BRASIL, 1875).

Ao lado do título eleitoral também se sedimenta o poder do juiz na administração das eleições. Desde muito tempo - com exceção das eleições inspiradas em Cádiz - o juiz era o presidente das eleições. A administração dos pleitos estava assentada, desde o início do Brasil, nas mãos dos juízes. Essa lei, no entanto, introduz um novo paradigma de atuação.

A lei do terço, em seus cento e sessenta e três artigos cita os juízes em duzentas e trinta ocasiões. Ainda que números não sejam adequados para avaliar leis, a dimensão do papel do juiz pode em parte ser vislumbrada com o dado e é confirmada pelo conteúdo das normas. O juiz decidiria com uma amplitude de poderes não antes vista em eleições do Brasil. Agora caberia ao juiz ir muito além da organização das eleições, ele era responsável por sua realização em uma dimensão mais abrangente.

Não é por poucos motivos que em janeiro de 1876, em manifesto às seções provinciais, esse fosse parte do discurso do Partido Liberal: 
Desejamos também que V. Exa. e seus colegas nos confiem o juízo que forem formando da alta administração provincial e dos magistrados, os quais vão desta vez exercer importante missão na sociedade brasileira. Deus queira que eles procedam de modo a merecer a bênção do país. Podem dar-nos ou tirar-nos de uma vez a esperança de termos verdadeiro e sério corretivo ao transviamento das paixões políticas (FERREIRA, 201, 243).

Agora não cabia apenas ao juiz de paz a organização das eleições. A justiça eleitoral passou a ser a responsável por decidir as questões relativas aos dois graus do processo eleitoral (CANDIDO, 2010, p. 29-30). A jurisdição atuaria de maneira muito mais significativa, há até mesmo a definição de um segundo grau de jurisdição, a ser feito para as Relações, conforme artigos 80 a 85 da norma.

A partir desse momento, se pode vislumbrar o judiciário com o papel de protagonista maior na organização das eleições, ainda que pressionado constantemente por fatores políticos locais e nacionais. Ele era fundamental antes, mas de um ponto de vida administrativo. A partir de agora, ele era responsável por todo o complexo sistema de alistamento, do voto, da apuração, em suma, dos diversos momentos do sistema eleitoral. Ao longo das instâncias, os membros da magistratura também se firmavam como o ponto principal de resolução das controvérsias.

A Lei do Terço parece ser o marco normativo mais relevante de entrega dessa relevante responsabilidade administrativa e política aos magistrados. Como se observará, em cerca de meio século isso se reafirmaria com o surgimento de um ramo inteiro da organização judiciária para esse fim - a Justiça Eleitoral.

\subsection{Lei Saraiva}

A Lei do Terço foi um avanço significativo para os fins aqui estudados - reafirmou o poder dos magistrados, criou o título de eleitor. No entanto, ela também não representou a solução dos problemas políticos relacionados às eleições e as discussões continuaram. Em $1^{\circ}$ de janeiro de 1878, o imperador toma a decisão de instituir eleições diretas (com apenas um grau). O caberia ao Partido Liberal - que por vinte anos já lutava por essa alteração - a tarefa de criar uma lei realizando a profunda alteração (FERREIRA, 2001, p. 257).

O primeiro incumbido foi o Visconde de Sinimbu, que se incompatibilizou com o imperador e teve que renunciar. Sinimbu acreditava que a pretendida alteração demandaria a reforma da Constituição, o que contraria os interesses do monarca. Qualquer oportunidade política de alteração da carta constitucional poderia significar a circunstância adequada para lhe retirar poder. A busca por outro liberal foi encerrada com a escolha de José Antônio de Saraiva, político de capacidades elogiadas por seus pares. 
Também nesse momento adentra na história do Brasil um jovem deputado de primeiro mandato, de 31 anos de idade, e incumbido de elaborar o texto da lei - Ruy Barbosa (BRASIL, 2009, p. 11). Barbosa, em discurso, lutava pelo fim do voto censitário, mas a eleição direta foi o máximo alcançado naquele momento. Era um dos passos iniciais de um dos mais capazes políticos do Brasil.

Em 9 de janeiro de 1881, o Império do Brasil viu ser assinada a Lei Saraiva, ou Lei do Censo, a mais avançada legislação eleitoral elaborada no Império do Brasil. A importância da lei era reconhecida e uma cerimônia solene é feita na entrega da lei para sanção do imperador. Essa seria a mais técnica e profunda lei eleitoral do império. Apesar da importância, as circunstâncias logo determinariam sua revogação, a república viria apenas oito anos depois (FERREIRA, 2001, p. 259-260).

Pelo Decreto n. 3.029, o imperador sancionou a Lei Saraiva e suas inovações. Essa lei deve ser vista como o marco de encerramento do império, o final de setenta anos de evoluções eleitorais em um ambiente inóspito. Por ter durado pouco, ela não é tão importante socialmente. Como norma, no entanto, ela é um dos auges do sistema eleitoral, o fruto de uma longa experiência de conflitos, feita após um longo período de experiências e falhas. Somada ao seu decreto de regulamentação, ela ocupou mais de setenta páginas em sua publicação (BRASIL, 1881).

A Lei Saraiva derrogava todas as leis eleitorais anteriores e também retirava todos os rituais religiosos da eleição (BRASIL, 2009, p. 12). Ela estabeleceu que a eleição de todos os cargos eletivos no Brasil seria feita por meio de eleições diretas.

\footnotetext{
Art. $1^{\circ}$ As nomeações dos Senadores e Deputados para a Assembléa geral, membros das Assembléas Legislativas Provinciaes, e quaesquer autoridades electivas, serão feitas por eleições directas, nas quaes tomarão parte todos os cidadãos alistados eleitores de conformidade com esta lei. A eleição do Regente do Imperio continúa a ser feita na fórma do Acto Addicional á Constituição Política pelos eleitores de que trata a presente lei (BRASIL, 1881).
}

$\mathrm{O}$ voto continuava censitário pelo artigo $2^{\circ}$ e com requisitos adicionais de renda para senador e deputado. O longo artigo $3^{\circ}$ determinavam os possíveis meios de prova de maneira detalhada, considerando as diversas formas de renda existentes na sociedade.

A exceção criada nesse aspecto foi a cargos do governo, que de acordo com o artigo $4^{\circ}$, não precisariam comprovar rendas. São eles: ministros, conselheiros de estado, bispos, presidentes de província e seus secretários, senadores, deputados da Assembleia Geral e Provincial, magistrados, promotores públicos, chefes de polícia, diretores de secretarias e de 
empresas públicas e autarquias, empregados do corpo diplomático, diretores de faculdades, professores de escolas de instrução superior, graduados. Uma interpretação para essas exceções poderia ser a vontade de incluir um relevante número de funcionários do governo, interessados na manutenção do sistema - cerca de $77 \%$ do eleitorado do Rio de Janeiro, por exemplo, foi isento de prova.

Alguns dos meios de prova se mostram bastante flexíveis, até mesmo os alugueis de moradias poderiam ser utilizados. Apesar disso, o eleitorado brasileiro diminui sensivelmente depois da lei, possivelmente pela necessidade apresentar as provas estabelecidas. O voto não era obrigatório, o alistamento era opcional e dependia de expressa manifestação.

A existência de distritos era fundamental na organização. Haveria um distrito para cada deputado a ser eleito na Assembleia Geral, preferencialmente, dividindo a população da província. A votação para deputado, no entanto, dependia da maioria absoluta de votos. Caso ela não fosse alcançada imediatamente haveria um segundo turno e nele concorreriam apenas os dois mais bem votados - normas contidas no artigo 18 .

Para as eleições provinciais, mais de um deputado seria eleito em cada distrito. Apesar disso, cada cidadão votaria em apenas um nome. A noção de coeficiente eleitoral ${ }^{8}$ foi aplicada. Aqueles deputados que tivesse o número suficiente para preencher uma quota seriam imediatamente eleitos. Se sobrassem vagas, haveria um segundo turno (art. 18, $\S 3^{\circ}$ ).

Crimes eleitorais também são previstos em dezesseis tipos no artigo 29, além da reafirmação dos três presentes no Código Criminal. Alguns dos crimes eram: apresentar-se com o título eleitoral de outrem para votar; apresentar-se para o voto mais de uma vez na mesma eleição; deixar o juiz de alistar o cidadão que tenha comprovados os requisitos; impedir ou dificultar a reunião da omissão eleitoral no local do pleito; aproximar-se do local de voto portando armas.

De disposições gerais sobre os eleitores, se mantinha a idade mínima geral de 25 anos, 21 anos para os casados ou oficiais militares e nenhuma restrição para os bacharéis ou clérigos. Também continuavam restritos os votos dos filhos-família, dos empregados que não fossem guarda-livros, primeiros caixeiros, criados da casa imperial e administradores de fazendas e fábricas (Decreto ${ }^{\circ} 8.213$ de regulamentação da Lei Saraiva, parágrafo $2^{\circ}$ ).

\footnotetext{
8 Coeficiente eleitoral, ou quoeficiente eleitoral se exemplifica da seguinte forma: se há três cargos a serem ocupados e noventa mil votos realizados, um coeficiente eleitoral estará formado se trinta mil pessoas votarem em um eleitor. O artigo 106 do atual código eleitoral o define em teoria assim: "Determina-se o quociente eleitoral dividindo-se o número de votos válidos apurados pelo de lugares a preencher em cada circunscrição eleitoral, desprezada a fração se igual ou inferior a meio, equivalente a um, se superior." (BRASIL, 1965).
} 
Apesar das grandes inovações, na primeira eleição direta realizada compareceram às urnas apenas 96.411 eleitores, um número muito reduzido, se considerado que haviam cerca de 1 milhão e 100 mil eleitores aptos a votar naquelas eleições. O sistema político brasileiro ainda estava bastante longe de envolver a população em massa (FAORO, 2001, p. 698).

Os juízes mantiveram seu papel de protagonistas na Lei Saraiva. Não houve modificações significativas sobre a realidade da Lei do Terço (FERREIRA, 2009, p. 278-279).

O papel de organização se mantinha. Muitos são os artigos em que se cita a magistratura. A título de exemplo, pode-se apontar o início da lei, quando no artigo $6^{\circ}$, se explicita o papel do juiz de organizador do alistamento eleitoral (art. $6^{\circ}$ ) e presidente da mesa eleitoral (art. 15, $\S 7^{\circ}$, I). Suas tarefas de administrador maior são mantidas. Surgidos os conflitos, cabia a eles dirimi-los, nos termos do artigo 28 - seus poderes eram bastante amplos nesses casos.

No aspecto jurisdicional, o poder da magistratura segue os mesmos traços. Os problemas eleitorais que surgissem deveriam ser resolvidos pelo próprio juiz. O artigo 18 da lei entrega expressamente para eles a jurisdição sobre o local onde se apuraria o eleito do distrito. O juiz não era responsável apenas pela organização, mas também pela realização das eleições.

O Decreto 8.213, que regulamentou a Lei Saraiva, também deixou clara a extensão do poder do juiz. O artigo 70 dá poder ao juiz de direito para resolver todas as tarefas relacionadas ao alistamento, ainda que coubesse recurso à Relação. Posteriormente, ainda foi editado o Decreto número 7.981 em 29 de janeiro de 1881, explicitando com ainda mais detalhes o papel do juiz de Direito nas eleições.

Assim, podemos visualizar na Lei Saraiva a continuidade do papel do magistrado no que tange ao processo eleitoral. Ele era uma peça do maior relevo nas engrenagens eleitorais. A tentativa de moralização das eleições, ainda que falha, evoluíram com amplo uso da figura de um juiz.

A Lei Saraiva foi o último marco relevante no Direito Eleitoral do Império Brasileiro. Em 1889, a República dos Estados Unidos do Brasil seria implantada com a força de um golpe militar. A partir desse momento, os 14 milhões de habitantes brasileiros viveriam um regime novo, mas no qual a legislação eleitoral ainda estaria imersa em um ambiente político conturbado e incapaz de estabelecer uma democracia saudável. O saldo do período não era animador, mas houvera avanços - cerca de $10 \%$ da população votava naquele período. É um número excessivamente pequeno, mas que seria diminuído para menos de $1 \%$ quando as leis republicanas retiraram a necessidade de renda, mas impuseram a necessidade de alfabetização, criando uma barreira ainda maior (CARVALHO, 2006, p. 24). 


\section{CONCLUSÃO}

O Direito Eleitoral no Período Imperial foi marcado pelas dificuldades sociais e uma alteração constante de leis. O objetivo de tantas alterações era aprimorar o sistema e estabelecer um modo funcional de aplicar a política no Brasil. Não houve êxito nessa tentativa, mas parece ter havido melhorias. A Lei Saraiva foi um instrumento mais democrático e com mais ferramentas do que as anteriores haviam sido.

É notável, também, como o magistrado foi reafirmado como o principal administrador das eleições nacionais. Esse papel era tradicional, remete à tradição de eleições municipais durante a colônia desde o século XVI, mas sua inserção dentro do sistema das eleições gerais garantiu que ele permanecesse exercendo o papel fundamental, em uma tradição que auxiliaria na criação da Justiça Eleitoral em fevereiro de 1932.

A análise normativa, afinal, permite se observar a implantação de um sistema eleitoral essencialmente liberal em um país ainda despreparado para fazer valer seriamente o Império do Direito. O resultado não foi sempre positivo, mas o quadro permite notar as constantes tentativas de moralizar e aprimorar o sistema.

\section{REFERÊNCIAS}

ARMITAGE, John. Historia do Brazil desde a chegada da real familia de Bragança, em 1808, até a abdicação do Imperador D. Pedro I, em 1831. Rio de Janeiro: Typ. Imp. e Const. de J. Villeneuve e Comp, $1837 . \quad$ Disponível em: <http://www.Brasíliana.usp.br/bbd/bitstream/handle/1918/00187000/001870_COMPLETO.p df>. Acesso em: 29 dez. 2014.

BERBEL, Márcia Regina. La Constitución española en el mundo luso - americano (1820-1823). Revista de Índias, Volume 68, Número 242, 2008. Disponível em: <http://revistadeindias.revistas.csic.es/index.php/revistadeindias/article/view/641/707>. Acesso em: 29 dez. 2014.

BERBEL, Márcia Regina. Os apelos nacionais nas cortes constituintes de Lisboa (1821/22). In A independência brasileira: novas dimensões. Rio de Janeiro: Editora FGV, 2006, p. 184.

BONAVIDES, Paulo. As Nascentes do Constitucionalismo Luso-Brasileiro, Uma Análise Comparativa. Disponível em: <http://biblio.juridicas.unam.mx/libros/4/1510/9.pdf>. Acesso em: 21 fev. 2015. 
BONAVIDES, Paulo. História Constitucional do Brasil. Brasília: 1989.

BONAVIDES, Paulo; AMARAL, Roberto. Textos Políticos da História do Brasil. Volume I. Brasília, Senado Federal, Conselho Editorial, 2012, pp. 491-492.

BONAVIDES, Paulo; ANDRADE, Paes de. História Constitucional do Brasil. Brasília: 1989. BRASIL. Constituição Política do Império do Brazil. Disponível em: <http://www.planalto.gov.br/ccivil_03/Constituicao/Constituicao24.htm>. Acesso em: 08 fev. 2015 .

BRASIL. Decreto $n . \quad 2.675$, de 1875. Disponível em: <http://www.tse.jus.br/eleitor/glossario/termos/lei-do-terco>. Acessado em: 22 mai. de 2015.

BRASIL. Decreto $n^{\circ} 8213$, de 13 de agosto de 1881. Regula a execução da Lei ${ }^{\circ} 3029$ de 9 de janeiro do corrente ano que reformou a legislação eleitoral. Coleção das Leis do Império do Brazil, Rio de Janeiro, v. 2.

BRASIL. Lei 4.737, de 15 de julho de 1965. Disponível em: < http://www.planalto.gov.br/ccivil_03/leis/14737.htm >. Acesso em: 21 fev. 2015.

BRASIL. Lei de $1^{o}$, de outubro de 1828. Disponível em: <www.planalto.gov.br/CCIVIL_03/LEIS/LIM/LIM-1-10-1828.htm>. Acesso em: 21 fev. 2015.

BRASIL. Lei dos Círculos - Decreto n. 842, de 1855. Disponível em: <http://www.tse.jus.br/eleitor/glossario/termos/lei-dos-circulos>. Acesso em: 21 fev. 2015.

BRASIL. Tribunal Superior Eleitoral. Títulos eleitorais: 1881-2008. Brasília: Tribunal Superior Eleitoral, Secretaria de Gestão da Informação, 2009.

CAIRÚ, José da Silva Lisboa, Visconde de. Historia dos principaes successos politicos do Imperio do Brasil (Parte X). Rio de Janeiro: Na Typographia Imperial e Nacional, 1827. Disponível em: <http://www.Brasíliana.usp.br/bbd/bitstream/handle/1918/00858820/0085882_COMPLETO.pdf $>$. Acesso em: 21 fev. 2015.

CANDIDO, Joel J. Direito Eleitoral Brasileiro. 14ª ed. Bauru: ERIPRO, 2010.

CARVALHO, José Murilo de. Os Três Povos da República. Revista Usp, São Paulo, num. 59, p. 96-115, setembro/novembro 2003.

CINTRA, Antonio Carlos de Araújo; PELLEGRINI GRINOVER, Ada; DINAMARCO, Cândido Rangel. Teoria Geral do Processo. 23ª . São Paulo: Malheiros Editores, 2007.

CONSTANT, Benjamin. Principes de Politique, Aplicables à tous les Gouvernements Représentatifs et Particulièrement à la Constitution Actuelle de la France. Paris: Chez Alexis Eymery, 1815. 
FAORO, Raymundo. Os Donos do Poder. Formação do Patronato Político Brasileiro. $3^{\mathrm{a}}$ ed. São Paulo: Editora Globo, 2001.

FERREIRA, Manoel Rodrigues. A Evolução do Sistema Eleitoral Brasileiro. Brasília: Senado Federal, 2001.

FRANCO, Afonso Arinos de Mello. Estudos de Direito Constitucional. Avenida Erasmo Braga, 299: Revista Forense, 1957.

FRANCO, Afonso Arinos de Melo. O Constitucionalismo de D. Pedro I Bo Brasil e em Portugal. Brasília: Ministério da Justiça, 1994.

GOMES, Laurentino. 1808. Como uma rainha louca, um príncipe medroso e uma corte corrupta enganaram Napoleão e mudaram a História de Portugal e do Brasil. $2^{\mathrm{a}}$ Edição. São Paulo: Editora Planeta, 2011.

HOMEM DE MELlO, F. I. Marcondes. A Constituinte Perante a História. Rio de Janeiro: Typographia da Actualidade, 1863

JORGE, José Alfredo Luiz. Direito Eleitoral. Campinas: Millennium Editora, 2004.

JUL, José Manuel Sanjurjo. La artillería naval en el siglo XVIII y en la Batalla de Trafalgar. 2004. Disponível em: < http://ruc.udc.es/dspace/bitstream/2183/9013/1/CC89art1.pdf >. Acesso em: 24 fev. 2015..

MAIA, Fernanda Paula Sousa. O discurso parlamentar português e as relações PortugalBrasil: a câmara dos deputados (1826-1852). Fundação Calouste Gulbenkian, 2002.

MELLO MORAES, Alexandre José. Historia do Brasil-reino e Brasil-imperio comprehendendo: A historia circumstanciada dos ministerios, pela ordem chronologica dos gabinetes ministeriaes, seus programmas, revoluções politicas que se derão, e cores com que apparacerão, desde a dia 10 março de 1808 até 1871. Rio de Janeiro: Typ. de Pinheiro \& C., 1871.

MICHELS, Vera Maria Nunes. Direito Eleitoral: de acordo com a Lei ${ }^{\circ}$ 9.503/97. Porto Alegre: Livraria do Advogado, 2002.

PORTO, Walter Costa. O Voto no Brasil - da Colônia à $6^{a}$ República. 2.ed. revista. Rio deJaneiro: Topbooks, 2002.

PORTUGAL. Diário das Cortes Geraes e Extraordinarias da Nação Portugueza. Primeira legislatura, primeira sessão legislativa, número 18, ata de 19 de fevereiro de 1821. Lisboa, 1821-1822. Disponível em: 〈http://debates.parlamento.pt/?pid=mc〉. Acesso em: 21 fev. 2015.

PORTUGAL. Ordenações Filipinas. Rio de Janeiro: Cândido Mendes de Almeida, 1870. Disponível em: <http://www1.ci.uc.pt/ihti/proj/filipinas/11p153.htm>. Acesso em: 21 fev. 2015.

PRADO JÚNIOR, Caio. Evolução Política do Brasil. Colônia e Império. São Paulo: Editora Brasiliense, 2010. 